\title{
READING THE BOOK OF JOB AND CAMUS'S LA PESTE DURING COVID-19
}

\author{
Erwin Susanto \\ Boston College \\ lferwin.susanto@gmail.com
}

\begin{abstract}
The pandemic crisis that is COVID-19 has caused unprecedented suffering throughout the world. At such a time, the religious person can legitimately ask why God allows this and how one's faith might wrestle with such tragedy. In my search of the Scriptures to respond to these questions, I find the Book of Job to be a fruitful dialogue partner-be it in the way it urges one to consider aspects of suffering that are not apparent or in how it resists attempts at oversimplifying God's character. In this essay, I compare the Book of Job with Albert Camus's novel La Peste, the latter being set during an epidemic. I argue that both literary works provide space for a theological voice to recognize and articulate suffering in terms of divine justice; both works also enable one to resist any concrete framework for explaining suffering. I then suggest that La Peste complements one's reading of Job as Scripture by highlighting both the importance of active response to suffering as well as the relational dimension of suffering in the world, which should prove to be helpful in this time of crisis and beyond.
\end{abstract}

Keywords: Book of Job, Albert Camus, The Plague [La Peste], COVID-19, suffering, problem of evil, biblical interpretation

Abstrak
Pandemik COVID-19 telah menyebabkan penderitaan di seluruh
dunia dalam skala yang sebelumnya tidak terbayangkan. Di saat
seperti ini, orang beriman dapat dibenarkan untuk bertanya
mengapa Allah mengizinkan hal ini dan bagaimana iman seseorang
dapat bergumul dengan tragedi seperti ini. Dalam pencarian saya di
dalam Kitab Suci untuk merespons kepada pertanyaan-pertanyaan
tersebut, saya menemukan Kitab Ayub sebagai rekan dialog yang
berguna-baik dalam caranya mendorong seseorang untuk
memikirkan kembali aspek-aspek penderitaan yang tak tampak
ataupun ketia ia menolak cara-cara yang terlalu menyederhanakan


karakter Allah. Di dalam tulisan ini, saya membandingkan Kitab Ayub dengan novel Sampar karya Albert Camus, yang mana berlatar belakang kisah di sekitar sebuah pandemik. Saya berargumentasi bahwa kedua karya tulis tersebut menyediakan ruang bagi suara teologis untuk menyadari dan mengartikulasikan penderitaan dalam terang keadilan ilahi; kedua karya tersebut juga memampukan pembaca untuk menolak setiap bingkai yang kaku dalam menjelaskan penderitaan. Setelah itu, saya menyarankan bahwa Sampar dapat melengkapi pembacaan terhadap Ayub, yang adalah Kitab Suci, dengan menegaskan pentingnya respons aktif terhadap penderitaan dan juga dimensi relasional dari penderitaan di dalam dunia, yang mana akan berguna bagi manusia yang hidup di masa krisis saat ini dan setelahnya.

Kata-kata Kunci: Kitab Ayub, Albert Camus, Sampar [La Peste], COVID-19, penderitaan, masalah kejahatan, interpretasi biblis.

\section{Introduction}

Suffering has never ceased to fascinate me. Not least because it is something I am familiar with, like almost everyone else, but also because it is puzzling and paradoxical in many ways. For example, suffering inflicts a sense of isolation, but at the same time it unambiguously demonstrates that this human condition is shared by virtually every person. Perhaps even more importantly, suffering triggers the realization of one's need for God while simultaneously planting doubt whether God is good or even real, as the pain gets deeper underneath the skin.

Indeed, questions about suffering are even more urgent now in the face of the COVID-19 pandemic crisis. While suffering might not have failed to show up in one's environment or in the media, human suffering can often appear banal to those numbed by its ubiquity and perceived distance. The pandemic has changed that, at least for now. Not only has this public health crisis flooded the news and conversations on a daily basis, it has affected so many persons at an unprecedented scale. These stories—of the sick, the dying, the despairing, the jobless, the abandoned, the hungry, the separated, those risking their lives just to work at a store, and healthcare workers struggling to treat the dying-are much more vivid, given that almost everyone is affected in one way or another. Furthermore, despite technological progress, human civilizations remain helpless before the onslaught of this invisible, infinitesimal virus. Pope Francis has given a reminder recently how much this stormy period has revealed false certainties as well as the need for God. Nevertheless, he did not forget to press a bit upon the other 
side of this paradox, which is the silence of God amidst this great, universal suffering. ${ }^{1}$

This difficult question, about God and suffering, was probably why the Book of Job was written, preserved, and handed down for thousands of years. The book poses and speaks to the question: if one needs God and turns to God, especially in times of trouble, why does a good God still allow such a person to suffer greatly? This perennial question has ensured that the Book of Job never ceases to attract a deluge of interpretations, from ancient times until the contemporary period. Today, that question has come to the fore once again, as the pandemic wreaks havoc on the lives of so many people, and I feel urged to follow in the long tradition of searching the book for resources to respond. Given that my primary interest in this endeavor is to read the Book of Job for the benefit of those suffering under the sign of this pandemic, my considerations are largely contextual rather than historicalcritical (as if to participate in the academic exercise of debating past interpretations of the book-worthy an effort as that may be), with methodological assistance from a literary approach to this scriptural text as a whole.

Furthermore, given the challenge of reading the Book of Job in the context of a disease outbreak, which does not happen in the book, I will also use another literary work that has achieved the status of a modern classic, La Peste by Albert Camus, in my interpretation. While it has continued to receive attention from scholars and lay readers alike, Camus's work has surged in popularity among a wider audience recently because it reflects many issues faced by societies today in the context of COVID-19, given that a disease outbreak, albeit much more localized, is the setting of the book. Certainly, Camus's novel has often been read in the context of political ideology, especially vis-à-vis fascism in Europe. Factors supporting this reading include the setting of the book in the 1940s and also the fact that Camus wrote it while he was part of the French Resistance against Nazi Germany in Vichy France. Opponents of fascism at the time found the book unsatisfying, given only its ambiguous condemnation of fascism; on the other hand, such ambiguities allow the novel to transcend the era of World War II and context of Europe. ${ }^{2}$ It contains a great amount of reflection on perennial questions about suffering, death, exile, and separation. ${ }^{3}$

\footnotetext{
${ }^{1}$ Francis, "Pope at Urbi et Orbi: Full Text of His Meditation," Vatican News, accessed September 3, 2020, https://www.vaticannews.va/en/pope/news/2020-03/urbi-et-orbi-popecoronavirus-prayer-blessing.html.

${ }^{2}$ Tony Judt, introduction to The Plague by Albert Camus, ed., Tony Judt, trans., Robin Buss (London: Penguin Books, 2001), 9-11.

${ }^{3}$ Ibid., 4-6.
} 
Although Job and La Peste have received plenty of individual attention for their explorations of suffering and evil, they surprisingly have not invited as much mutual comparison. I have been able in the present season of quarantine to obtain three meaningful treatments for the purposes of this essay. ${ }^{4}$ One article compares Job and La Peste with the added perspective of the Bhagavad Gita, while another is mediated by Fyodor Dostoevsky's The Brothers Karamazov, on the premise that Dostoevsky is well known to have been influenced by the Book of Job. The most recent work compares Job and La Peste in the context of the Shoah.

When read in the context of the current crisis, I have found that the Book of Job is helpful in the way it pushes the reader to consider sufferings that might not be apparent and in the way it complicates any attempt to oversimplify the meaning of suffering. I have also found that my interpretation is augmented when I read both Job and La Peste directly side by side. While there are some similarities, there are also thematic differences that allow La Peste to supplement a reading of the Book of Job in two ways. The first is La Peste's emphasis on action; the second is the novel's attachment to the social aspect of suffering. The Book of Job, more often than not, is much more interested in the suffering of Job as an individual who has lost his dignity and property rather than as a person who has lost relationships.

Following the present introduction, I begin to explore how the Book of Job might speak to its readers in the current pandemic crisis. As this is a synchronic reading for a contextual interpretation, I assume the literary unity of the text. ${ }^{5}$ Afterwards, I discuss two ways in which La Peste is similar to Job, and then two thematic differences between them, which enhance the interpretation of the Book of Job. At the end of the paper, I sum up and conclude with some thoughts on what both works might have to say about the end of the pandemic crisis, if it does end in the near future.

4 Peter Slater, "Evil and Ultimacy," Studies in Religion, Vol. 4, No. 2 (1974): 137-146; Andrea Lešić-Thomas, "The Answer Job Did Not Give: Dostoevsky's Bra'tia Karamazovy and Camus's La Peste," The Modern Language Review, Vol. 101, No. 3 (2006): 774-788, https://doi.org/10.2307/20466909; Matthew H. Bowker, "The Meaning of Absurd Protest: The Book of Job, Albert Camus, and C. Fred Alford's After the Holocaust," Journal of Psycho-Social Studies, Vol. 5, No. 1 (2011): 163-183.

${ }^{5}$ For readers interested in a diachronic reading, see Carol A. Newsom, The Book of Job: A Contest of Moral Imaginations (New York: Oxford University Press, 2003), 201-202. Newsom argues for single authorship of the text, except for the late addition of Elihu's speeches. She essentially shifts the burden of proof to those arguing for literary disunity given the lack of manuscript evidence and then proceeds by showing how single authorship is plausible if the reader does not assume that Job was composed for a linear reading intuitive to many modern readers. 


\section{The Book of Job and COVID-19}

\section{Setting the Stage}

The Book of Job begins with a description of Job as a morally perfect man with tremendous wealth, followed by revelation of a deal between God and the Adversary to test Job on whether he will curse God upon losing everything the man possesses (Job 1:1-12). ${ }^{6}$ This sets up the context of the book, as narrated by an omniscient narrator. As such, the reader of the book knows the reason why Job suffers, while Job himself does not.

The beginning of the book has at least two important implications for readers attempting to interpret Job in the contemporary context. The first, more straightforward implication is that Job's lack of knowledge allows the reader to identify with his suffering. Precisely because he does not know why disasters fall upon him, there is warrant today for putting oneself in his shoes. After all, the reader does not know why this great pandemic has fallen upon our world. Certainly, one might be able to attribute the crisis to natural causes. It could be said that constant deforestation or failure to regulate "exotic" (an etic category) wildlife markets has exposed humans to unknown microorganisms. One could easily blame governments for the lack of transparency or weak infrastructure that enabled SARS-CoV-2 to spread, mutate, and then proliferate even quicker. Even if these opinions are accurate, one might be able only to explain the pandemic's material, formal, and efficient causes - to borrow Aristotelian categories. The final cause, which is the purpose of the outbreak, seems to be beyond the reach of sciences, or perhaps beyond human knowledge. When the question is asked in the context of an individual sufferer, it becomes even more difficult to explain. Graduating college students, for example, might ask, "Why must this happen as I am about to graduate and look for a job to pay off my student loans?" For all intents and purposes, the pandemic looks like an accident over which no one has any control. However, a religious person who believes in the existence of God like Job can legitimately ask, "Why is God allowing this to happen?" In fact, such a person cannot help but ask the question.

The second, more problematic implication is that the Book of Job is telling its reader that God is willing to let the best servant suffer greatly in order to prove a point. It is certainly true that ancient readers would not find suffering inflicted by God as troubling as we do. ${ }^{7}$ Moreover, the book does not tell us if God is

\footnotetext{
${ }^{6}$ The verse numbering used here follows the English translations of the text.

7 Andrew R. Davis, "Job," in The Paulist Biblical Commentary, eds., José Enrique Aguilar Chiu, et. al. (New York: Paulist Press, 2018), 433.
} 
either curious about the outcome or simply cannot allow a challenge from a subordinate to remain unanswered. This has been left ambiguous. Nevertheless, the point remains that God easily agrees to allow great suffering to fall upon a morally perfect servant for the sake of a bet, leading to no small anger on the part of the unknowing Job. This unusual portrayal of God is also likely to be intentional, given that subverting existing tradition frequently happens in the Book of Job. ${ }^{8}$ Now, it is unlikely that the reader is being asked to accept this easy agreement as God's modus operandi outside of this literary world, for the author of Job does not claim to understand the nature of God. Not only is God depicted very differently compared to other biblical traditions, the divine speech and the ending, as we shall see later, do not resolve the raging debate between Job and his friends about God and justice. Thus, it is not useful to use this characterization of God at the beginning of the story as a lens to understand divine behavior. What is useful, however, is that this unusual portrayal is likely the book's suggestion for its readers to embrace the possibility that God does not think or behave in the way God is often thought to be. In common parlance, it is to "let God be God."

Now, it is of no comfort either to put oneself in Job's position unaware of the reason behind great suffering inflicted upon the individual or to abandon (at least temporarily) any familiar notions about God's nature or character. Yet, the setup of the book seems to demand such attitudes if one is to encounter the force of the riddle that the author of Job has put before the reader.

\section{Disaster upon Disaster}

Once the stage has been set, the Adversary proceeds to do what God has permitted to be done; disaster falls upon Job, one after another. The first three result in the destruction of his property and the death of his servants, while the fourth results in the death of all his children (1:13-19). The final one manifests as an assault on his body, in the form of an illness that marks his entire body, turning him into an outcast (2:7-8). Thus, calamity strikes what is furthest from Job, his wealth, before moving on to his children, and eventually his own body. In turn, Job's response also follows a pattern. After the destruction of his property and the death of his children, the omniscient narrator tells us that Job does not $\sin (1: 22)$. However, after Job is afflicted with a terrible disease, the narrator qualifies that Job does not sin with his lips (2:10). After

${ }^{8}$ Carol A. Newsom, "The Book of Job," in The New Interpreter's Bible Commentary, Vol. IV, ed., Leander E. Keck (Nashville, TN: Abingdon Press, 1996), 395-396. 
his three friends visit, even his lips are no longer restrained as he curses his birth and blames God for his misfortune $(3: 1,23)$.

Since the COVID-19 crisis affects so many different people differently, there are certainly those who respond like Job and those who do not. The pattern of Job's loss that begins with his property all the way to his health is more useful for reflecting on the current situation. A pandemic crisis naturally makes one think that the greatest loss is health and human life. Fortunately, the media remind us that there are also grave economic and social losses, particularly individuals who lose their jobs because the nature of their job does not allow them to work from home. The progression of Job's losses, however, urges the reader to consider whether there are also those who experience the same sequence as Job. One is asked to wonder if there are those who, upon losing their jobs and property due to the pandemic, also end up losing relationships and health. I think it is not difficult to imagine persons forgotten by society and the media whose financial problems, as a result of the pandemic, end up fracturing their family relationships. Neither is it difficult to imagine that many of those who became unemployed are forced to risk their health by taking on frontline work to survive financially. In the context of the United States, for example, despite massive recruitment drives by Amazon and grocery stores, unemployment continues to rise rapidly (at the time of writing). This can be explained by the fact that those who lose their jobs or businesses are pressed to take up any job to make ends meet, even if it means higher risk of falling sick, especially if their new employers are not known for providing decent employee welfare. ${ }^{9}$

The scriptural text, moreover, invites readers to pay attention to human agency that effectively amplifies suffering in this health crisis, when one considers the fact that two of Job's disasters are immediately (though not ultimately) caused by human agents, the Sabeans and the Chaldeans. ${ }^{10}$ More obvious to us today is the failure of governments to be transparent and quick in their responses. However, in the American context, factors like the loss of health insurance due to rising unemployment and an inability to quickly protect jobs through government subsidy can be attributed to long-running policies, based on an ideology of individualism,

${ }^{9}$ Dana Mattioli, “A Month Ago, They All Had Stable Jobs. Now They Want to Work for Amazon," April 9, 2020, The Wall Street Journal, accessed September 3, 2020, https://www.wsj.com/articles/a-month-ago-they-all-hadstable-jobs-now-they-want-to-work-for-amazon-11586424601.

10 This reading does not consider the famous passage found in chapter 24 where Job laments about social injustice. This is because in the first half of the chapter, his complaints appear to be merely rhetorical tools for polemicizing against God. As for the second half at 24:18-25, the passage is controversial because Job seems to contradict himself, making it likely that it was originally Zophar's missing third speech reassigned to Job. 
which resists systematic governmental intervention in social programs.

\section{What Explainers Would Say}

Once all the disasters have befallen Job and he is left alone as an outcast, his three friends come to comfort him (2:11-13). Soon after, the compassionate visit turns into a passionate debate that makes up the largest portion of the book. Commentator Andrew Davis cautions fellow readers not to dismiss Job's friends too quickly as foolish and uncaring as many commentators often do, perhaps because it is too easy to adopt Job's viewpoints of them. ${ }^{11}$ Instead, the reader should consider Carol Newsom's proposal that the genre of wisdom dialogue demands that both sides of a discourse be taken seriously. ${ }^{12}$ As such, to do justice to the text, I attempt below to state the arguments of both sides in the strongest way I can.

Newsom argues that the first strategy embarked upon by Job's friends, particularly Eliphaz and Bildad, is to create a narrative of Job's life where his current suffering could be inserted into the middle portion of that narrative. ${ }^{13}$ By doing this, they are able to speak of a hopeful future where his suffering will cease. This is conditional, however. Furthermore, Davis points out that this way of reasoning is only possible because of Job's exemplary past. Thus, Job can hope beyond the present crisis because he was a friend to the troubled in the past. ${ }^{14}$ Job, however, would have none of it. He responds that the present is the most important because it is the moment when his body is driven to cry out from pain and injustice. In fact, there is no good reason for him to believe that he could endure his present pain until that so-called hopeful future comes to relieve his suffering. ${ }^{15}$ Strikingly, Eliphaz and Bildad's strategy is widely reflected today in many voices during this COVID-19 crisis. During the early phase of the pandemic, many politicians used this strategy to confidently assure the public that the society will get over this in the near future. A notable example in the US is how President Trump claimed that the pandemic will disappear, without any extraordinary step needed to contain it-an approach for which he has been widely criticized. These voices touting that everything will get better, however, betray their privileged position of having sufficient means to survive the crisis. Unlike his three friends, however, Job is suffering, and his pain cannot wait. In the same way, there is no future for those who have died from

\footnotetext{
11 Davis, "Job," 435.

${ }^{12}$ Newsom, The Book of Job, 90-91.

${ }^{13}$ Newsom, The Book of Job, 101-102. For example, see 4:3-5; 8:21.

14 Davis, "Job," 435.

${ }^{15}$ Newsom, The Book of Job, 134-135. For example, see 6:11.
} 
COVID-19 or from lack of medical treatment due to overwhelmed facilities, and there is no future "normal" for those who have lost their loved ones. The jobless and those who are forced to take risky jobs are wondering if they can even survive the current crisis, whether financially or even physically. Job's response, then, urges the reader to look unflinchingly at the present. It is one thing to be hopeful of the future; it is another thing to use the future as an excuse to ignore the plight of the presently suffering.

Another strategy employed by Job's friends, as Newsom points out, is to urge Job to seek God and pray. ${ }^{16}$ Borrowing Philippe Nemo's language, Newsom argues that each of his three friends is essentially asking Job to use prayer as a kind of technique to take control of his situation. ${ }^{17} \mathrm{Job}$ is skeptical of this and he seems to notice that prayer assumes inequality between the supplicant and the patron deity. ${ }^{18}$ In response, Job turns to the use of legal metaphors in order to create a neutral space for his dispute with God. ${ }^{19}$ As Davis points out, there are precedents for this because legal disputes between God and humans are well known in other biblical traditions, especially in prophetic literature. ${ }^{20}$ However, in those traditions God is the one who brings a lawsuit, whereas here it is Job who sues God instead. ${ }^{21}$ Like the unusual portrayal of God in the heavenly court scene, this reversal demonstrates once again the willingness of the book to subvert earlier traditions in its exploration of the question of suffering. This should serve as a reminder to the reader what I set up at the beginning of this interpretive endeavor, which is an unknowing state of mind and an openness to any notion of God. That said, unlike Job, I am not willing to go as far as stating confidently that God is the efficient cause of the great suffering in this pandemic crisis. Job's polemic against God does not contain compelling arguments on why he is right to bring a lawsuit against God. Perhaps the omniscient narrator in the book has a better case, but like Job, the reader is not omniscient in the context of COVID-19. Blaming God with legal metaphors, in the current situation, does not help anyone. Besides, the central question is the final cause, the why, and not so much about the agent who causes it. Even if one can be sure that God is the efficient cause, one is still left asking about the purpose. The reality, however, is that one is unable to know God's nature and modus operandi. Thus, there is nothing

${ }^{16}$ For example, see 8:5 and 8:20.

17 Philippe Nemo, Job and the Excess of Evil (Pittsburgh, PA: Duquesne University Press, 1998), 44, quoted in Newsom, The Book of Job, 127-129.

18 Newsom, The Book of Job, 129, 156-160.

${ }^{19}$ Davis, "Job," 438.

${ }^{20}$ Ibid.

21 The first speech Job makes to accomplish this can be found in chapter 9 . 
wrong with embracing prayer in faith (pace Job) while coping with this pandemic crisis. More importantly, if Newsom and Nemo are right, what is troubling about the strategy employed by Job's friends is the sole use of prayer as a technique to take control of the situation. While most contemporary religious groups, fortunately, do not see prayer as mutually exclusive from taking practical steps, there are religious leaders, such as those in American televangelist circles, who claim that they are able to invoke God's power to heal those afflicted by COVID-19. This attempt to use prayer as a technique for seizing control of the situation is especially dangerous when it is combined with an individualistic political ideology. One could then claim that one should be able to resume "normal" life, thanks to some kind of divine protection, without consideration of the potential harm of such a reckless behavior before a vaccine or cure is found. A less troubling but more widespread attitude about the pandemic, which resembles the recommendation of Job's friends to take control through prayer, is that praying for a sufferer implies that there is no need to do anything else for the person in pain or trouble. It is good for the religious person to pray, but one must also take practical steps to help the suffering and be wary about attempting to take control of what in fact cannot be controlled.

The third and final strategy discussed here is the iconic narrative offered by Job's three friends. Newsom argues that they seem to think of evil as some kind of thing that is self-destroying and subject to disintegration because it has no ontological relation to the order of creation. ${ }^{22}$ According to Newsom, this iconic narrative of the short-lived nature of evil, for Job's friends, is the best explanation for why institutions in society can exist in a stable manner. ${ }^{23}$ After all, if evil is permanent and self-sustaining, it would constantly compromise the social order. This approach to narrative has been used by many Christian preachers to argue that since God is all-good and all-powerful, the best explanation for disasters is that the victims deserve them. On the other hand, if their groups are flourishing, the best explanation is that God is pleased with them. Unfortunately, there is no shortage of such preachers even during this COVID-19 crisis that has inflicted suffering on the entire world. But fortunately, such preachers are usually unable to persuade mainstream society of their narrative. However, in the context of the United States, there is a more widespread and persistent iconic narrative that threatens to resist future reforms of the healthcare and welfare systems. It is the so-called "American dream." This iconic narrative has been used to explain the

${ }^{22}$ This is found in most passages about the fate of the wicked man. For example, in 15:17-35.

${ }^{23}$ Newsom, The Book of Job, 121-125. 
successes of immigrants in the past, the good fortune(!) of selfmade billionaires, and the economic strength of the nation. By insisting that most hardworking individuals will succeed, the narrative assumes the opposite, which is that most individuals who do not succeed (usually financially) have not persevered or worked hard enough. This pandemic crisis, which might last for a long time, has revealed that poorer communities are disproportionately affected and that the American welfare and healthcare systems are not resilient enough in times of crisis. Yet, resistance to the reform of these systems remains strong, even among those who would benefit from such overhauls. Job's response to his friends is very appropriate and useful when applied to contemporary US context, as he argues that iconic narratives depend on highly selective examples. And he does this by reminding his friends of wicked individuals who flourish, thereby greatly angering Eliphaz in the process (21:7-34). ${ }^{24}$ In the same way, if the painful lessons of this pandemic are not to be wasted once the US as a nation begins to reflect on the pandemic, presumably once it is contained, the reader is called to learn from Job and to point out why the American dream narrative is highly selective in public civic discourses.

\section{The Divine Response}

I now proceed to the climax of the book, where God gives his response from the whirlwind. ${ }^{25}$ Having been challenged by Job, God appears to challenge him back with a dizzying list of images to demonstrate that Job is not God, effectively agreeing with Job's friends that God is radically different from humans. For the reader looking for a reason for Job's suffering, however, the divine response is a non-answer. God does not tell Job about the bet God makes with the Adversary and does not give Job any reason whatsoever for his pain. The suffering Job remains unknowing and puzzled. The Book of Job, therefore, appears to refuse to give its reader any kind of license to try to explain the great suffering inflicted by the COVID-19 pandemic crisis. This is prudent because disasters are often explained away by blaming other people, and this refusal to rationalize great suffering was the approach that Pope Francis took in his rare Urbi et Orbi address (it was given for the pandemic, although normally reserved for Easter, Christmas, and a newly elected pope). Speaking in an empty square, Pope Francis dwelled on the question whether God cares, the same one asked by Jesus's disciples during a storm. He did not try to explain why the pandemic could inflict so much suffering if God

24 Ibid., 162-164.

25 I am not discussing Job's last speech and Elihu's speeches to avoid redundancies and also due to lack of space here. 
cares, but insisted that God certainly cares, because Jesus did save his disciples when called upon. ${ }^{26}$

Now, while popular interpretation of the divine speech often stops at God saying to Job that divine logic is incomprehensible, it is possible to say more. Davis suggests that the disorientation resulting from the awesome cosmic and mythical images is God's attempt to decenter Job from the focus of the discourse. ${ }^{27}$ Newsom, however, goes much further. She argues that the divine speech represents the nonmoral and nonrational aspect of God and that it is fundamentally opposed to Job's worldview that demands some kind of moral order grounded in reality that can explain his suffering. ${ }^{28}$ This can be seen in the creatures that God delights in, whether it is the wild animal that scorns the city, or the agile ostrich that has no wisdom, or the Leviathan that receives 34 (or five, depending on the chosen poetic structure) verses of divine praises in chapter 41 . The attention to Leviathan is particularly striking given that in other biblical traditions, it is typically a mythical, chaotic monster of cosmic proportions to be vanquished by the divine warrior. Thus, Newsom contends, there is a tragedy in the collision between the human Job's desire for rational understanding of suffering against the chaotic aspects of God and the world that elude this very human desire. ${ }^{29}$ Job's demand and the divine response show that, while the sufferer will never stop trying to understand the cause of suffering and to seek to live in a way that can keep his or her family and world secure, such an attempt can never succeed. ${ }^{30}$ If Newsom is right, the Book of Job tells the reader that one may go on asking for the meaning behind the pandemic crisis, in the same way Job persists in his query about his suffering, but no satisfying answer can ever be expected. ${ }^{31}$ Even more disturbing is the deliberate non-mention of human beings in the divine tour of the universe, except for the horse rider mocked by the ostrich $(39: 18)$ or the slain corpses available as food for hawks (39:30). The glorification of both

${ }^{26}$ Francis, "Urbi et Orbi."

${ }^{27}$ Davis, "Job," 459.

${ }^{28}$ Newsom, The Book of Job, 252-253.

${ }^{29}$ It is notable that Newsom's interpretation appears to bear some influence from the philosophical theme of absurdity, which is prevalent in Albert Camus's writings. See Bowker, "The Meaning of Absurd Protest," 168-170.

${ }^{30}$ Newsom, The Book of Job, 252-253.

${ }^{31}$ Michael Fox provocatively argues that the theophany actually reveals that God needs human help to rule the world. While this is an interesting interpretation, it relies on an assumption that is difficult to demonstrate. Fox assumes that God's silence on human beings in the divine speech could show God's positive evaluation of human beings but he does not give an argument on why it should be read that way. See Michael V Fox, "The Meanings of the Book of Job," Journal of Biblical Literature 137, no. 1 (2018): 13-14, 18, https://doi.org/10.1353/jbl.2018.0001. 
wilderness and forces of chaos in the divine speech, in opposition to human civilization, may remind the reader of how SARS-CoV2 , indeed, comes from the wild and-perhaps more so than Leviathan-could bring entire civilizations to their knees. Yet, the God of Job would show admiration for it as much as for Leviathan, precisely because of its might, about which researchers and medical workers are still discovering more and more from day to day.

\section{The Epilogue}

To segue to the epilogue, it is worthwhile to go over the preceding discussions thus far. In reading Job within the context of the COVID-19 crisis, one can see that the book begins by asking its reader to be radically open-minded on the nature of God, despite the doctrines that might have been received. Through consideration of its narration concerning the disasters that fall upon Job, one can fruitfully read these scriptures as urging one to consider less obvious kinds of suffering and to identify human agency that worsened the pandemic crisis. The arguments of Job's three friends, meanwhile, can be read as reflecting unproductive or even dangerous voices, whether it is about the privileging of the future or the use of prayer as technique for seizing control or the abuse of iconic narratives. On the other hand, Job's responses to his friends could offer today's reader some insight on how one could respond to those voices. Useful points include Job's privileging of the present and his exposure of iconic narratives as biased and selective. Then, the divine speech shows that just as Job receives a non-answer, even open-mindedness cannot help the reader to discover the final cause of suffering in this crisis. Searching for a complete answer is, therefore, a fruitless attempt. If anything, the divine speech makes it easier to see God as complicit with the forces of chaos that ravage today's societies.

Moving on to the puzzling ending of the Book of Job, we see that Newsom interprets the prose ending as showing that Job uncomfortably accepts the tragedy and moves on by living with whatever he has been given, despite not knowing anything about why he suffers. She suggests that the strange names of his daughters, which are "dove," "cinnamon," and "horn of eye shadow" (a kind of cosmetics), might reflect Job's act of tragic laughter, not too different from the foolish but laughing ostrich (39:18). ${ }^{32}$ Davis largely agrees, arguing that the failure of the dialogue between Job and his friends demonstrates that Job's constant fixation over his suffering is unsustainable. Eventually, Job's "new normal" life and all its mundanities must resume. ${ }^{33}$ There are other problems too. For example, there is this strange

${ }^{32}$ Newsom, The Book of Job, 256-259.

${ }^{33}$ Davis, "Job," 464-465. 
twist where, despite being angry with what Job's friends have said, God's restoration of Job's property ends up proving his friends to be correct earlier on (22:21-27; 42:6). Nevertheless, it appears that Job does move on because he no longer attempts to question God, despite his earlier passionate speeches. This conclusion to the Book of Job, or at least this interpretation, can be unsettling to the reader trying to make sense of great suffering amidst the ongoing crisis. The divine speech suggests that finding the final cause of suffering is a hopeless endeavor, such that the epilogue seems to imply that the reader can only move on to a "new normal"—as if life could really return to normalcy.

Thus, I now turn to Albert Camus's La Peste in an attempt to augment the above interpretation. While the protagonists in $L a$ Peste are also denied any kind of framework for making sense of suffering, Camus's approach can be more productive for the modern sufferer. True enough-La Peste was not written to be canonized as Scripture; neither is there any evidence that the Book of Job was written to be included among the scriptures either. Besides, it was unlikely that there was any notion of canonization at that time. As such, rather than contrasting these two works as a scriptural book and a profane work, my approach here is to see both works as human attempts, ancient and modern, to make sense of great human suffering. With this comparative approach, hopefully, the reader can draw out more resource for the contemporary situation.

\section{The Book of Job and La Peste}

\section{Searching for Common Ground}

Despite the large number of studies done on each work individually, there is hardly any comparative reading of Job and $\mathrm{La}$ Peste to be found in scholarly literature. Perhaps this is because of the massive categorical differences between the two works. While not exhaustively, I list below the biggest differences, so as to contextualize each and to avoid comparative readings that are overly forceful. First of all, Job was written more than two millennia ago, while La Peste was published only within the past century. The chasm in cultural attitudes found in each work is difficult to cross. Second, the metaphysical worldview in each work could hardly be more disparate. Despite Job's furious demands upon a deity whom he is willing to consider as unjust, he still believes that God is real and therefore available to entertain the appeal that Job makes. In La Peste, on the other hand, many main characters explicitly mention they do not believe in God. Thirdly, the genres are very different. The Book of Job contains proses told by an omniscient narrator and wisdom dialogue in the form of 
poetry. La Peste, in contrast, is a modern novel composed entirely in prose and narrated by the protagonist. Fourth, the Book of Job is mainly concerned with the struggle of its namesake protagonist. La Peste, however, is interested in the suffering of an entire city. Finally, the kind of suffering is also different. While the destruction of Job's wealth and property are central in his laments, La Peste does not show much concern with financial loss. Moreover, while Job's disease is a painful one, the point of the affliction seems to be more about shame and being cast out from society rather than the threat of death (hence his complaint that he did not die). The plague disease in La Peste, meanwhile, is so deadly that the sufferer can barely participate in a conversation once symptoms appear and often dies soon after.

Despite differences between these great literary works, there are two similarities worth exploring. In Camus's novel, consider the first sermon of Father Paneloux, one of the main characters who is a French-Algerian Catholic priest. At the start of the epidemic, Paneloux preaches that the outbreak is a punishment from God, and, thus, only the unjust need to be fearful. This echoes the iconic narrative of Job's three friends on the fate of the wicked, that ultimately the wicked will be punished while the pious will prosper. It is unlikely that this similarity is a coincidence because Paneloux explicitly counts Job among the accursed because of their sins, although he does not say what Job's sin is. ${ }^{34}$

The other, more interesting similarity provides the basis for my attempt later to supplement my reading of Job. I have discussed how the divine speech represents the chaotic aspect of God that resists human desire to establish a moral order. This, of course, is not to say that there is no moral order. Rather, the takeaway from Job is the realization that it is impossible to account for all instances of suffering and evil, no matter how much one wishes to do so. Camus's La Peste essentially aligns with this conclusion. In the only scene to gather all of its main characters, the book tells of a new vaccine being tried as a last resort on a magistrate's dying child. This gathering is so extraordinary that one might be fooled into thinking this to be the climactic turn when the disease would be defeated at last. Instead, the long and tortured narration of the boy's struggle to survive ends with his painful death. Protagonists Dr. Rieux and Fr. Paneloux are both deeply affected by the child's death but in different ways. Rieux loses his composure immediately but is able to regain it. Paneloux, on the other hand, is completely changed. Not only does Paneloux give a second sermon that is near to heresy (at least according to the omniscient narrator), but he also

34 Furthermore, it has been argued that Camus was influenced by Dostoevsky, who in turn had been influenced by the Book of Job. See LešićThomas, "The Answer Job Did Not Give," 774-776. 
succumbs to the disease soon after delivering that sermon. Puzzlingly, Rieux diagnoses Paneloux's disease as both the plague and not the plague, as if to say that Paneloux's attempt to reconcile his theology with the death of the child had led to the priest's demise. Thus, the character who attempts to understand suffering in abstract terms (in this case, in terms of punishment) does not survive. As observed by Andrea Lešić-Thomas, this trend continues with the death of another main character at the end of the book, Jean Tarrou, who also grapples with suffering with an abstract ideology. ${ }^{35}$ Unlike Paneloux, Tarrou does not seek to explain suffering and he does not think in a religious way. ${ }^{36}$ Instead, he sees his voluntary participation in the healthcare teams as part of his aspiration to become a "secular saint." One could say that this is the latest incarnation of his ideals, having been a former revolutionary fighter and an opponent to the death penalty (controversial at that time). In contrast, the surviving main characters are those with no abstract ideals-be it Rieux, a physician who aspires to simply be "a man," or Joseph Grand, a clerk who is obsessed with writing a little book, or Raymond Rambert, a journalist who is single-minded in attempting to escape the city to rejoin his lover. ${ }^{37}$

Here lies the second similarity between the Book of Job and Camus's La Peste that provides the basis of my comparison between the two works. The divine speech, which is the climax of the book, denies Job an explanation for his suffering. As a result, the human sufferer is forced to live without understanding even at story's end. Job could only go on living with the new circumstances given to him. Camus, on the other hand, does not permit main characters with abstract ideals in their approach to the plague, whether religious or not, to survive the epidemic. Rieux, Grand and Rambert move on with their life and make no attempt whatsoever to protest or understand the plague. In short, both works assert that chaos is not overcome by order. This point is expressed not only in the progression of the plot, but also through important symbols. God's divine speech in the Book of Job praises Leviathan, the representative of chaos, as a creature with no equal. Camus's authorial pen in La Peste vaunts the plague, which brings an entire city to its knees, as a devastating force disappearing as suddenly as it had struck. Camus's narrator, in fact, takes care to mention that there has been no change in the treatment methods and no evidence that the new vaccine is effective, despite the best efforts

35 Ibid., 785.

${ }^{36}$ It is often debatable as to what "religious" means. In this case, I am merely juxtaposing the categories of Christian and secular thinking for clarity's sake, controversial as that could be sometimes.

${ }^{37}$ Peter Slater, "Evil and Ultimacy," 143. 
of the doctors. Camus's plague-that leviathanic force of chaossubsides, not because it has been defeated, but rather (as the narrator suggests) because it has fulfilled its role.

\section{Augmenting Job with La Peste}

Having discussed the similarities between the two works, it is now time to supplement my reading of Job with La Peste through consideration of their thematic differences. The Book of Job ends tragically. Job's desire to account for suffering will never be fully satisfied. The only way forward is to move on with life while struggling with this reality. In some sense, La Peste too ends with tragedy. Main characters with grand visions end up perishing, protagonists lose loved ones, and the plague is undefeated by human effort - all the while, the reader is reminded that the plague could return as suddenly as it disappeared. Thus, both the Book of Job and La Peste affirm the human inability to fully understand suffering. However, there is a key difference in the way this tragedy unfolds. For Job, he is constantly obsessed with trying to understand his suffering, before his attempt becomes frustrated in the end. In contrast, the main characters of La Peste are mostly preoccupied with their healthcare work. This is especially apparent in the character Rieux who is single-minded in his work of healing, even if he sees its futility; he suffers(!) no illusions in what he is trying to do, laboring on despite enduring endless defeat. Thus, while the main point of the Book of Job is the unintelligibility of suffering, $L a$ Peste goes further in its concern not to let the unintelligibility of suffering have the last word. ${ }^{38}$ In this way, La Peste supplements the above reading of Job by reminding the reader that it is not enough for one to accept the unintelligibility of suffering and to refuse to explain away its final cause. Rather, one must do everything in one's power to minimize suffering in society, even if one does not know its final cause. It is in fact possible to read in La Peste a little encouragement. While the plague disappears not because of any truly successful human intervention, the work of the healthcare teams certainly reduced the maximum impact of the plague.

Another way in which La Peste can supplement a reading of Job is seen in its emphasis on the social aspect of suffering. The Book of Job focuses on Job's suffering as a person who has lost both his prosperity and dignity. The loss of his children does not seem to amount much more than the loss of his property, and this is consistent with ancient attitudes about children. Indeed, the survival of the wife does not seem significant to him either, given

38 Ibid., 142. 
that Job only interacts with her once in most translations. ${ }^{39}$ As a result, the above reading of Job in the context of COVID-19 is mostly concerned with the individual sufferer's loss of material goods. La Peste, on the other hand, emphasizes from the beginning that the very first implication of the plague is exile, resulting from the separation of loved ones as the city comes under quarantine. For instance, Rieux is unable to meet his wife, who undergoes treatment in the mountains and eventually dies before the quarantine is lifted; Rambert is obsessed with the idea of escaping, so that he can return to his lover in France; Grand is preoccupied the entire time with articulating the opening line for his novel, which turns out to be about his wife who had left him. The child who died in that aforementioned extraordinary scene becomes motivation in absentia for his father, a local magistrate who volunteers to help with quarantine camps in memory of his lost son; tragically, even the magistrate also dies by the end of the story. Then, there is the scene when Tarrou dies a painful death, witnessed only by his new-found close friend, Rieux, and his mother. It is particularly poignant because it happens unexpectedly just as Oran's citizens celebrate the imminent lifting of the quarantine. Indeed, when one reflects on the most heart-wrenching scenes in La Peste, almost all of them are concerned with separation, rather than the loss of dignity or material goods. There is rarely any show of concern for loss of property, except for mentions of rising prices and rationing of supplies. In this way, La Peste reminds the reader that suffering during COVID-19 is not only due to illness or loss of income-grave as they are. The novel invites the reader to think more about suffering as a result of forced separation from loved ones, whether due to mandatory quarantine or death by illness. La Peste also serves as a reminder that those who are able to stay together with their loved ones during this crisis should be grateful.

\section{Conclusion}

To sum up, I began this essay with the objective to read the Book of Job in the context of COVID-19, to see how it might speak to questions about suffering and the role of God. The Book of Job can stimulate fruitful readings in terms of how it helps the reader to notice less apparent suffering and unjust social structures in the context of COVID-19, as well as biased iconic narratives.

${ }^{39}$ See Sarojini Nadar, "Re-Reading Job in the Midst of Suffering in the HIV/AIDS Era: How Not to Talk of God," Old Testament Essays 16, no. 2 (2003): 347-48. Nadar argues that the role of Job's wife is integral to the discourse in the book. This is useful for contextual interpretation. But despite her role, Job nevertheless does not seem to cherish his relationship to her in either the prosaic or poetic sections. 
While the reader, like Job, might not be able to fully understand the final cause of this great crisis, it is nevertheless instructive that the reader can learn from the book not to try to explain it away. The novel La Peste, despite its many differences, contains enough similarities to warrant a comparative reading with Job that can helpfully supplement it. I find it especially useful that the modern classic encourages the reader to consider the non-material dimension of suffering, where the Book of Job does not. Of course, this meager attempt to compare these two great works falls far short of exhausting the potential benefits of such an endeavor.

Now, I would like to offer a final thought about the future. Like the citizens of Oran in La Peste, everyone is desperately hoping for the quarantine in our time to be over soon. Once the pandemic comes to its own sudden end, there will be plenty of celebrations. In the preceding section, I mentioned a particularly poignant scene in La Peste when Tarrou dies a slow death, just as many patients are recovering and as the city is lifting the quarantine. The narrator drives the point home by saying that it is even more painful to lose someone to the disease right when hopes are high everywhere else that the epidemic is ending. Thus, even when our pandemic is over, the novel invites us to remember those who cannot celebrate because they are still sick, or desperately trying to make ends meet, or losing their loved ones to the disease. Those who experience irreversible losses, such that any return to normalcy holds no meaning for them, must not be overlooked or forgotten. Perhaps the Book of Job would agree here. For Job is never said to be healed from his sores; intriguingly, the number of his new children is not double the sum of his dead children-even as God gives him twice the amount of the material wealth he had before. It is as if all these are reminders for Job, that the end of his time of mourning among the ashes does not entail definitive conclusion of his suffering, for the scars of his tribulation endure until death.

\section{About the Author}

Erwin Susanto recently completed his Master of Theological Studies and Master of Theology at Boston College School of Theology and Ministry, concentrating on biblical studies. He is currently in Singapore, working for the local chapter of Caritas in the areas of advocacy and formation. He enjoys reflecting and commentating on contemporary culture and issues.

\section{Bibliography}

Bowker, Matthew H. "The Meaning of Absurd Protest: The Book of Job, Albert Camus, and C. Fred Alford's After the Holocaust." Journal of Psycho-Social Studies, Vol. 5, No. 1 (2011): 163-183. 
Davis, Andrew R. “Job.” In The Paulist Biblical Commentary, eds., José Enrique Aguilar Chiu, et. al. New York: Paulist Press, 2018.

Fox, Michael V. "The Meanings of the Book of Job." Journal of Biblical Literature, Vol. 137, No. 1 (2018): 7-18. https://doi.org/10.1353/jbl.2018.0001.

Francis. "Pope at Urbi et Orbi: Full Text of His Meditation." March 27, 2020, Vatican News. Accessed September 3, 2020. https://www.vaticannews.va/en/pope/news/2020-03/urbiet-orbi-pope-coronavirus-prayer-blessing.html.

Judt, Tony. Introduction to The Plague by Albert Camus. Ed., Tony Judt, trans., Robin Buss. London: Penguin Books, 2001.

Lešić-Thomas, Andrea. "The Answer Job Did Not Give: Dostoevsky's Bra'tia Karamazovy and Camus's La Peste.” The Modern Language Review, Vol. 101, No. 3 (2006): 774-788. https://doi.org/10.2307/20466909.

Mattioli, Dana. "A Month Ago, They All Had Stable Jobs. Now They Want to Work for Amazon.” April 9, 2020, The Wall Street Journal. Accessed September 3, 2020. https://www.wsj.com/articles/a-month-ago-they-all-hadstable-jobs-now-they-want-to-work-for-amazon11586424601.

Nadar, Sarojini. "Re-Reading Job in the Midst of Suffering in the HIV/AIDS Era: How Not to Talk of God." Old Testament Essays, Vol. 16, No. 2 (2003): 343-357.

Nemo, Philippe. Job and the Excess of Evil. Pittsburgh, PA: Duquesne University Press, 1998.

Newsom, Carol A. The Book of Job: A Contest of Moral Imaginations. New York: Oxford University Press, 2003.

- "The Book of Job." In The New Interpreter's Bible Commentary, Vol. IV. Ed., Leander E. Keck. Nashville, TN: Abingdon Press, 1996.

Slater, Peter. "Evil and Ultimacy." Studies in Religion, Vol. 4, No. 2 (1974): 137-146. 